\title{
Suvremena znanstvena relevantnost Marxove analize kapitala (u povodu rasprave o knjizi Daga Strpića Robna proizvodnja i udruženi rad u Marxovoj kritici političke ekonomije)
}

\author{
ZDRAVKO PETAK \\ Fakultet političkih znanosti, Sveučilište u Zagrebu
}

\begin{abstract}
Sažetak
U radu se razmatraju relevantnost Marxove analize kapitala i značaj prikaza te analize u Strpićevoj knjizi o Marxovoj kritici političke ekonomije. Autor na početku rada naznačuje neke elemente općeg teorijskog okvira u koji je Strpić postavio svoje istraživanje Marxove kritike političke ekonomije. Nakon toga razmatraju se dva temeljna pitanja koja se tiču same Marxove kritike političke ekonomije: 1. Može li se iz Marxova teorijskog sklopa izvući temeljna potka za razumijevanje važnosti institucija u ekonomskom procesu na način na koji ih vide predstavnici starog i novog institucionalizma u političkoj ekonomiji? 2. Može li se iz čitanja Marxova kategorijalnog aparata izvesti jedinstveno razumijevanje ekonomskih kriza? U odgovoru na prvo pitanje pokazuje se da postoje određene sličnosti između Marxova i pristupa ekonomskih institucionalista, no isto tako i značajne razlike između tih dvaju pristupa. U odgovoru na drugo pitanje pokazuje se da Marx nije razvio jedinstvenu teoriju kriza, već da se u njegovu djelu mogu pronaći argumenti za dvije ili tri različite teorije kriza.

Nakon toga se u najopćenitijim crtama pokazuje da je Marxova kritika političke ekonomije prvenstveno situirana svojim odnosom prema klasičnoj školi, ali da posjeduje i određeni potencijal korespondiranja sa suvremenom ekonomskom znanošću. Autor pokazuje da se pravac te korespondencije odnosi prvenstveno na objašnjenje temeljnih tendencija u razvoju kapitalističkog sistema. U zaključku rada navode se neki od temeljnih Strpićevih doprinosa političkoj ekonomiji.
\end{abstract}

Ključne riječi: Marxova kritika političke ekonomije, institucionalizam u političkoj ekonomiji, Marxova teorija kriza, Marx i suvremena ekonomska znanost, Strpić 


\section{Marxova kritika političke ekonomije}

Rasprava o dosezima Marxove teorije danas se nerijetko odvija između dvaju pretjerano pojednostavljenih stajališta - a) da su Marxove analitičke postavke, s obzirom na znanstvene pogreške u ekonomskoj analizi i ideologiju nasilja koju je promovirao, danas neupotrebljive kao teorijsko objašnjenje dinamike modernih društava, i b) da je Marx predvidio sve temeljne značajke procesa koji prate današnju globalizaciju. Knjiga Daga Strpića Robna proizvodnja i udruženi rad u Marxovoj kritici političke ekonomije (Strpić, 2017), koja predstavlja autorovu doktorsku disertaciju obranjenu 1991. na Fakultetu političkih znanosti u Zagrebu, pokazuje da ozbiljno čitanje Marxa ne bi trebalo dovoditi do tako simplificiranih stajališta. U vjerojatno jednom od najboljih razmatranja Marxove kritike političke ekonomije u nas Strpić podastire sustavnu analizu Marxova kategorijalnog aparata, popraćenu impresivnom analizom prateće literature i sustavnih teorijskih izvođenja.

Strpićeva knjiga se po svojoj temeljnoj ambiciji zadržava na razmatranju ključnih stavova samog Marxa te njegova odnosa prema autorima klasične tradicije, nadasve Smithu i Ricardu. U tom smislu njegovo djelo ostaje u okviru ocjene koju je svojedobno dao Zvonimir Baletić da je "osnovni kriterij marksističkih teorijskih i empirijskih studija poslije Marxa bilo samo Marxovo djelo, te se izvan njega ne može naći pouzdanu osnovu od koje bismo polazili u samostalniju i kritičniju ocjenu Marxova rada u ekonomiji i njegovog značenja za analizu suvremenih ekonomskih zbivanja" (Baletić, 1968: 591). Ishodište Strpićevih nastojanja unutar takvog fokusa istraživanja jest, prije svega, Marxov odnos spram Adama Smitha i u tome se njegovo analitičko nastojanje u velikoj mjeri podudara s istraživanjima Ronalda Meeka podastrtim u knjizi Smith, Marx i poslije njih (Meek, 1977), premda se autor u toj knjizi nije ograničio samo na odnos Marxa i Smitha, već je nastojao polemizirati i o odnosu Marxa i marginalista.

Strpićevo djelo na tragu je najboljih sustavnih radova posvećenih Marxovoj kritici političke ekonomije (Becker, 1977; Foley, 1986; Hollander, 2008; Howard i King, 1985), u kojima se njegova teorija vrijednosti, kapitala i novca pokazuje prije svega kao svojevrsni nastavak i unapređenje klasične tradicije političke ekonomije. No posebno valja istaći dva autora s čijim je razmatranjem cjeline Marxova djela Strpić iskazao posebnu vezanost. Prvi je francuski teoretičar Jacques Bidet, s kojim se nekoliko puta susretao i raspravljao o teorijsko-metodološkim ishodištima Marxove analize primijenjene u Kapitalu. Na važnost tih susreta i teorijskih diskusija proizašlih iz njih za samog Strpića pregnantno ukazuje Dragutin Lalović u pogovoru Strpićevoj knjizi (Lalović, 2017: 442-451). Temeljem tih rasprava nastao je niz važnih tekstova Bideta, Strpića i njihovih suradnika. ${ }^{1}$ Ovdje ne možemo ulaziti

1 Rasprave su objavljene u dva navrata u časopisu Naše teme, u brojevima 10-11/1986 i 3/1989, te u časopisu Politička misao, u brojevima 4/1989 i 3/2009. 
u prikaz svih tih rasprava, već ćemo samo napomenuti da je u velikom izdavačkom projektu, objavljenom pod naslovom Critical Companion to Contemporary Marxism, koji je uredio zajedno sa Stathisom Kouvelakisom, Bidet među ključne autore koji su doprinijeli suvremenom marksizmu kritičkom analizom Kapitala naveo i Helmuta Reichelta (Bidet, 2008: 20). A upravo je Reichelt, zajedno s Bidetom, bio sudionikom zagrebačkih rasprava o važnosti Marxova Kapitala objavljenih u časopisu Naše teme, u dva broja tijekom 1986. i 1989. ${ }^{2}$

Drugi autor, Hans Ehrbar, profesor političke ekonomije na Sveučilištu Utah u SAD-u, nije s njim, poput Bideta, izravno komunicirao, ali je uspostavio agendu istraživanja Marxove kritike političke ekonomije koja je u nizu elemenata vrlo slična Strpićevoj. On je u svojim Anotacijama o Marxovu "Kapitalu” (Ehrbar, 2010), radu koji predstavlja najvažniji dio šire istraživačke platforme vezane uz Marxovu kritiku političke ekonomije, izveo jednu od najsustavnijih analiza čitanja Marxova Kapitala. Osim spomenutog rada, vezanog uz nastavu političke ekonomije na Odjelu ekonomije spomenutog sveučilišta, Ehrbar je priredio niz dodatnih anotacija koje minuciozno tematiziraju ostale Marxove radove. Isto tako, spomenuta platforma upućuje i na njegove najvažnije radove, među kojima se posebno ističu radovi o Marxovoj analizi podastrtoj u Kapitalu sa stanovišta kritičkog realizma (Ehrbar, 2000). Strpić spominje njegove doprinose u svojoj knjizi Karl Marx i politička ekonomija Moderne, ističući da Ehrbarove anotacije o Marxovu Kapitalu "podsjećaju na doprinos Rosdolskog" (Strpić, 2010: 15).

U nastavku rada nećemo ulaziti u cjelinu prikaza robne proizvodnje i udruženog rada u Marxovoj kritici političke ekonomije, već ćemo se samo osvrnuti na dva pitanja:

1. Može li se iz Marxova teorijskog sklopa izvući temeljna potka za razumijevanje važnosti institucija u ekonomskom procesu, onako kako su ih vidjeli klasični institucionalisti poput Thorsteina Veblena ili Johna Commonsa? Odnosno, kako ih danas vide historijski institucionalisti kao predstavnici novog institucionalizma, izrazito snažnog pristupa u današnjoj političkoj znanosti i političkoj ekonomiji?

2. Može li se iz čitanja Marxove kategorijalne aparature izvesti jedinstveno razumijevanje nastanka ekonomskih kriza?

${ }^{2}$ Na kraju uvodnog teksta u spomenuti zbornik Bidet posebno navodi intelektualna nasljeđa i autore koji su presudno utjecali na razvoj marksizma te odmah na početku, uz navođenje Frankfurtske škole i nasljeđa Antonija Gramscija, posebno ističe da su trojica autora - Kôzô Uno, Helmut Reichelt i Hans-Georg Backhaus, bitno utjecali na razvoj marksizma svojim interpretacijama Kapitala. Odmah nakon njih ističe i važnost Althusserovih studija te radova još nekoliko drugih autora (Bidet, 2008: 20-21). 
Nakon toga razmotrit ćemo ukratko, u obliku najopćenitije skice, neke elemente odnosa Marxova učenja i suvremene ekonomske znanosti te ukazati na značaj političko-ekonomskih istraživanja koja je u svojim radovima poduzeo Dag Strpić.

\section{Institucionalizam i Marxova kritika političke ekonomije}

Institucionalisti nerijetko ističu stav da se u Marxovoj kritici političke ekonomije naziru strukturni elementi neophodni za razumijevanje institucija koje usmjeravaju današnja društva. Možda snažnije od drugih to je izrekao nobelovac Douglas C. North, istaknuvši da Marx oblikuje, ocrtava koncept transakcijskih troškova objašnjavajući napetost između odnosa u proizvodnji i proizvodnih snaga. Inzistiranjem na razmatranju ukupnih društvenih odnosa, on vidi elemente koje neoklasična ekonomija ne vidi, poput institucija, vlasničkih prava (postavljajući režim vlasničkih prava nasuprot proizvodnom potencijalu novih tehnologija), države i ideologije (North, 1986; 2003: 181). U preglednom radu o izvorima novog institucionalizma Victor Nee stoga smatra da North priznaje Marxu da je predvidio postojanje pojave koja se u institucionalnoj ekonomiji označava pojmom transakcijskih troškova (Nee, 1998: 6). Institucije, shvaćene kao niz pravila koja postoje u nekom društvu, ključan su faktor koji utječe na transakcijske troškove. Temeljem toga North dokazuje da institucije koje omogućuju niže transakcijske troškove potiču ekonomski rast i opću gospodarsku uspješnost i obrnuto. ${ }^{3}$

No to ne znači, kao što uvjerljivo pokazuje Ellen Immergut (1998), da između Marxova pristupa i institucionalizma postoji znak jednakosti. Marksistički pristup ona svrstava u zasebnu grupu pristupa u društvenim znanostima, koji u shvaćanjima interesa, u razumijevanju političkih procesa i u svojoj temeljnoj normativnoj poziciji ima najveću sličnost s različitim društveno determinističkim pristupima kakvi primjerice postoje u sociologiji. Uspoređujući marksističke/društveno determinističke pristupe s institucionalističkim i bihevioralnim/utilitarističkim pristupima, ona ukazuje na temeljne razlike u shvaćanjima interesa, političkog procesa i temeljne normativne pozicije između tih triju pristupa (Immergut, 1998: 12). Prvo pitanje odnosi se na ulogu interesa. Bihevioristi smatraju da se istinske preferencije i interesi koje ljudi imaju ne mogu ustanoviti, zbog čega se istraživač mora osloniti na ponašanje pojedine osobe da bi utvrdio te preferencije. Drugim riječima, preferencije se po njihovu mišljenju otkrivaju tijekom ponašanja. Tako iskazane preferencije, prema mišljenju institucionalista, ne treba brkati sa stvarnim interesima koje ljudi imaju. Unutar pristupa novog institucionalizma interese se razmatra kao ishod odnosno rezultat političkog procesa - kao nešto što je transformirano prolaskom kroz hijerarhijske strukture vlasti. Za razliku od njih u okviru marksizma i različitih oblika

${ }^{3}$ Sustavni prikaz Northove institucionalne teorije dao je Vojmir Franičević u pogovoru njegovoj knjizi Institucije, institucionalna promjena i ekonomska uspješnost. V. Franičević (2003). 
društvenog determinizma interesi su objektivno zadana kategorija, koja ima ishodište u klasnoj strukturi društva.

Drugo pitanje odnosi se na ulogu koju u tim pristupima ima politički proces. Institucionalisti snažno ukazuju na problem agregiranja preferencija i smatraju ga izrazito spornim momentom. Naime, dok bihevioristi smatraju da postoje neupitni mehanizmi agregiranja preferencija i njihova pretvaranja u kolektivni izbor, pripadnici novog institucionalizma odbacuju takvu mogućnost. Oni smatraju da političke odluke nisu zasnovane na agregaciji pojedinačnih preferencija jer su interesi u tolikoj mjeri kompleksni da nije moguće govoriti o njihovu sumiranju i temeljem načina njihova zbrajanja objašnjavati politički proces. Oni smatraju da se unutar institucionalnih mehanizama interesi ustvari preoblikuju, a ne da se sumiranjem pretvaraju u kolektivne odluke. Zbog toga, prema mišljenju pripadnika novog institucionalizma, mehanizmi kolektivnog izbora ne odražavaju zbroj pojedinačnih preferencija. Za razliku od institucionalista marksisti shvaćanje političkog procesa izravno povezuju s klasnom strukturom društva.

Treće pitanje odnosi se na temeljnu normativnu poziciju koju zagovaraju pojedini pristupi. Prema mišljenju novih institucionalista, najveći dio političkog ponašanja je rezultat procedura koje su upotrijebljene u procesu donošenja odluka. Institucionalni okvir donošenja odluka stvara zastranjenja (biases), koja je potrebno istražiti želi li se poboljšati proces kolektivnog odlučivanja. Drugim riječima, institucionalisti smatraju da je potrebno istražiti smjer i posljedice tih biasa kako bi se provelo unapređenje institucionalnog okvira. Takva je normativna ambicija jedno od ključnih mjesta u normativnoj poziciji institucionalista. Naime, institucije snažno utječu na ponašanje pojedinaca - one ga mogu u značajnoj mjeri ograničavati, ali i poticati. Promjenom institucionalnog okvira koji je na djelu u pojedinoj zajednici može se u bitnome promijeniti ponašanje pojedinaca, što zastupnike novog institucionalizma snažno dovodi do stava da se substantivna pravednost ostvaruje promjenom formalnih procedura.

Prethodno navedene razlike navele su niz autora da istaknu divergentne elemente koji su na djelu između marksizma i institucionalizma. Ankarloo i Palermo (2004), polazeći od marksističkog stajališta, kritiziraju stajališta Olivera Williamsona, dobitnika Nobelove nagrade za ekonomiju 2009. i jednog od najznačajnijih predstavnika novog institucionalizma. Zamjeraju mu da se ne pita o tome na koji su način uopće nastale pojedine vrste ekonomskih odnosa, odnosno na koji su način povijesno gledano nastale institucije kapitalizma. Drugu vrstu kritike podastrli su Heijdra, Lowenberg i Mallick (1988) navodeći da su novi institucionalizam i marksizam dva konkurentna pristupa koji imaju različita stajališta o nastanku, održavanju i promjeni institucija, te su u svojim zaključcima sugerirali prednost institucionalističkog pristupa u odnosu na pristup koji polazi od marksizma. 
Brojni su autori, s druge strane, odbacili logiku isključivanja, ističući značajne sličnosti dvaju pristupa. Dorman (1991) kritizira pretjerano inzistiranje na međusobnoj isključivosti pozicija tih dvaju pristupa, zalažući se za njihovu konvergenciju kao važan oblik daljnjeg razvoja heterodoksnih pristupa u političkoj ekonomiji. Dugger i Sherman (1994: 102) tako ističu da marksizam i institucionalizam u značajnoj mjeri dijele isto razumijevanje društva. O'Hara (2000) ide još dalje, nastojeći objediniti stajališta Karla Marxa i Thorsteina Veblena, jednog od najznačajnijih predstavnika starog institucionalizma. Na taj način pledira za svojevrsno objedinjavanje različitih heterodoksnih pristupa, kojima bi se premostile više nego očite razlike između Marxovih i Veblenovih stajališta.

Naravno, u Marxovoj teoriji i njegovom razumijevanju strukturnih napetosti postoje i nemali problemi. Kao što je, primjerice, pokazao Mancur Olson u svom djelu Logika kolektivnog djelovanja: javna dobra i teorija skupina (Olson, 2009), Marx je stavljao prevelik naglasak na učinke klasne borbe, zanemarujući konflikte unutar same klase. Olson je uvjerljivo pokazao da se velike, heterogene skupine teško pokreću bez dodatnih selektivnih poticaja. ${ }^{4} \mathrm{Na}$ tom tragu danas se u teoriji javnih politika razlikuju koncepti mreža javnih politika i zajednica javnih politika, gdje prvi izraz označava velike, heterogene skupine koje teško poduzimaju kolektivno djelovanje, za razliku od zajednica kao malih, homogenih skupina koje lako koordiniraju kolektivno djelovanje i stvaraju probitke za svoje članove.

\section{Marxova teorija ekonomskih kriza}

Drugo pitanje koje želimo raspraviti odnosi se na Marxovo razumijevanje pojave ekonomskih kriza. Strpić u knjizi Robna proizvodnja i udruženi rad u Marxovoj kritici političke ekonomije (Strpić, 2017), ali i u svojim drugim radovima pokazuje da se teorija krize izvodi približavanjem razini konkurencije mnogih kapitala. Marx, međutim, sustavni prijelaz na konkurenciju mnogih kapitala nije izveo. No izveo je mnoga približavanja, od kojih je najznačajnije, kako Strpić i pokazuje, izvođenje cijene proizvodnje, po uzoru na Davida Ricarda. Rezultat svega toga je činjenica, na koju upozorava James O'Connor, da "ne postoji nikakva posebna ili dominantna definicija krize bilo u Kapitalu ili u kasnijim marksističkim teorijskim radovima" (O’Connor, 1981: 302).

Zbog toga u Marxovoj političkoj ekonomiji "teorija kriza nije u potpunosti dovršena” (Itoh, 1978: 130), te se može nazrijeti nekoliko različitih tumačenja nastanka kriza. Itoh vidi dvije osnovne vrste teorija - teorije o višku kapitala i teorije o višku roba, koje nije lako pomiriti. No vidjet ćemo da je moguće izvesti i tri različita tumačenja teorije ekonomskih kriza, koja možemo označiti kao krize nedovoljne potrošnje, "iscjeđivanja” profita i hiperakumulacije kapitala.

4 Prikaz Olsonovih stajališta u domaćoj literaturi dao je Tonči Kursar (1997). 
U 15. poglavlju 3. toma Kapitala (odjeljak III. "Preobilje kapitala uz preobilje stanovništva") Marx govori o apsolutnoj hiperprodukciji kapitala:

Apsolutna hipeprodukcija kapitala postojala bi čim bi dodatni kapital za svrhu kapitalističke proizvodnje bio $=0$. Ali svrha kapitalističke proizvodnje jeste oplođavanje vrednosti kapitala, tj. prisvajanje viška rada, proizvoda viška vrednosti, profita. Prema tome, čim bi kapital narastao u takvom odnosu prema radničkom stanovništvu da se ne može uvećati apsolutno radno vreme koje to stanovništvo daje, ni proširiti relativni višak radnog vremena...; kad, dakle, uvećani kapital proizvodi samo isto onoliku ili čak manju masu viška vrednosti nego pre svog uvećanja, onda bi došlo do apsolutne hiperprodukcije kapitala; tj. uvećani kapital $K+\Delta K$ ne bi proizvodio više profita ili bi proizvodio čak manje profita negoli kapital $K$ pre svog uvećanja za $\Delta K$. U tom bi slučaju došlo i do snažnog i iznenadnog padanja opšte profitne stope, ali ovog puta usled promene u sastavu kapitala koja ne bi poticala iz razvitka proizvodne snage već iz podizanja novčane vrednosti promenljivog kapitala (usled podignutih najamnina) $i$ iz njemu saobraznog pada $u$ odnosu viška rada prema potrebnom radu (Marx, 1977b: 212-213).

Hiperakumulacija kapitala pokazuje se na taj način kao pojavni oblik krize objašnjene teorijom o višku kapitala, kao prvom obliku teorije krize, koju je Itoh uočio kod Marxa. No u istom tomu Kapitala, ali njegovom 30. poglavlju, Marx na jednome mjestu kaže:

Onda bi krizu bilo moguće objasniti jedino nesrazmerom proizvodnje u raznim granama, kao i nesrazmerom u kojoj bi potrošnja samih kapitalista stajala prema njihovoj akumulaciji... Poslednji uzrok svih stvarnih kriza ostaje uvek siromaštvo masa i ograničenje njihove potrošnje, nasuprot težnji kapitalističke proizvodnje da proizvodne snage razvije tako da njenu granicu predstavlja samo apsolutna potrošna sposobnost društva (ibid.: 412).

U citiranom dijelu Kapitala Marx, smatra Itoh, drži “da se krize pojavljuju zbog prekomjerne proizvodnje roba u odnosu na potražnju” (Itoh, 1978: 131), što je posve drukčije objašnjenje nastanka kriza nego u primjeru koji je polazio od prekomjerne proizvodnje kapitala. Itoh stoga s pravom zaključuje da je, neovisno o tome što se u razdobljima kriza pojavljuju istodobno višak roba i višak kapitala, "neophodno da se razabere što je od njih fundamentalni uzrok kriza" (ibid.: 313).

U navedenom citatu iz 3. toma Kapitala, u objašnjenju kojim se naglašava da je posljednji uzrok kriza "siromaštvo masa i ograničenje njihove potrošnje", Marx de facto razvija objašnjenje koje se zasniva na teoriji nedovoljne potrošnje. No na sličnu vrstu argumentacije možemo naići i u nekim drugim njegovim radovima. Uzmu li se u obzir i drugi Marxovi radovi, moglo bi se i preformulirati prethodno navedenu taksonomiju kriza u njegovim radovima te govoriti o tri oblika teorije kri- 
za: teoriji nedovoljne potrošnje, teoriji "cijeđenja" profita (profit-squeeze) i teoriji hiperakumulacije kapitala. Za sva ta tri oblika objašnjenja nastanka kriza mogu se naći uporišta u Kapitalu i drugim Marxovim radovima. U Osnovima kritike političke ekonomije (Grundrisse) on u 3. poglavlju, posvećenom kapitalu (2. odjeljak - Prometni proces kapitala), ističe:

Svaki kapitalist zna da prema svom radniku ne stoji kao proizvođač prema potrošaču, pa želi da njegovu potrošnju, tj. njegovu sposobnost za razmjenu, njegovu najamninu ograniči što više. On prirodno želi da radnici drugih kapitalista budu po mogućnosti što veći potrošači njegove robe. Ali odnos svakog kapitalista prema svojim radnicima jest odnos kapitala i rada uopće, bitan odnos. Ali iluzija (istinita za pojedinog kapitalista, za razliku od svih drugih) da osim njegovih radnika sva ostala radnička klasa stoji prema njemu kao potrošač i razmjenjivač, ne kao radnik, već kao onaj koji troši novac, nastaje upravo uslijed toga. Zaboravlja se da, kako kaže Malthus, "sama egzistencija profita kod bilo koje robe pretpostavlja potražnju izvan potražnje radnika koji je robu proizveo", te zato "potražnja samog radnika nikad ne može biti dovoljna potražnja” (Marx, 1979: 268-269).

Premda Marx u Grundrissima još ne razmatra sustavne pretpostavke cikličnog kretanja ekonomije, iz prethodno navedenog ulomka jasno je da je postavio temelje za teoriju krize kao nedovoljne potrošnje. Može se reći da na taj način "razvija teoriju krize Sismondija i Malthusa, koji su se suprotstavljali Ricardovoj klasičnoj teoriji” (Itoh, 1978: 132) Drugim riječima, Marx u dijelu svojih radova razvija stavove koji snažno sugeriraju da uzroke ekonomskih kriza valja tražiti u nedovoljnoj potrošnji stanovništva, što je narativ koji su u velikoj mjeri kasnije koristili i mnogi nemarksistički ekonomisti kao objašnjenje nastanka ekonomskih kriza.

$\mathrm{S}$ druge strane, u nekim dijelovima njegova rada, primjerice u 2. tomu Kapitala, mogu se naći i argumenti kojima se krizu može tumačiti iscjeđivanjem profita (profit-squeeze), gdje se kriza objašnjava oskudicom radne snage koja dovodi do povećanja najamnina, a time i do opadanja profitne stope.

... onda se ima primijetiti samo to da se krize svaki put pripremaju upravo jednim razdobljem u kojem je dizanje najamnina opće i radnička klasa stvarno dobiva veći udio u dijelu godišnjeg proizvoda koji je namijenjen potrošnji (Marx, 1977a: $342)$.

Postoji, međutim, i treća vrsta objašnjenja nastanka kriza u Marxovoj kritici političke ekonomije, koja se najčešće i izvodi. Riječ je, dakako, o postavci o pretjeranoj akumulaciji kapitala, koja stvara strukturne napetosti koje dovode do tendencijskog pada profitne stope. Najsnažnija argumentacija takve vrste može se naći u 15. poglavlju 3. toma Kapitala. Marx nastoji pokazati da je pritom riječ o strukturnoj napetosti između sredstva (bezuvjetni razvitak društvenih proizvodnih snaga) 
i svrhe (oplodnje vrijednosti postojećeg kapitala), koja se periodično razrješava u krizama.

Krize su uvek samo trenutna nasilna rešenja postojećih protivrečnosti, silovite erupcije koje na trenutak ponovno uspostavljaju poremećenu ravnotežu... Pri tome su krize uvek krize hiperprodukcije kapitala, ne hiperprodukcije sredstava za proizvodnju i potrošnju kao takvih, već samo ukoliko su ona postavljena kao kapital... Hiperprodukcija kapitala ne znači zbog toga ništa drugo do hiperakumulaciju kapitala (Marx, 1977b: 210, 212).

Čitanje Strpićeve knjige (Strpić, 2017) pomaže nam da se izvučemo iz tih, na prvi pogled, kontradiktornih tumačenja nastanka ekonomskih kriza. Pritom je osobito važno Strpićevo plediranje za cjelovitim razumijevanjem kriza, koje je posebno došlo do izražaja u njegovim kasnijim djelima Karl Marx i politička ekonomija Moderne (Strpić, 2010) i Prema Novoj političkoj ekonomiji (Strpić, 2015). U njima je ukazao na važnost istraživanja političkih, ali i ostalih neekonomskih izvora krize. On, primjerice, kritizira tvrdnje da "glavninu javno-političkog posla treba prepustiti ekonomskoj znanosti - kroz ekonomsku politiku”, ističući da su uzroci cikličkih ekonomskih kretanja po svojoj prirodi nerijetko neekonomski - te se "ponajviše pokazuju kroz cjelinu javnih politika" (Strpić, 2010: 146). U tome su posebno zanimljiva njegova pozivanja na Josepha Schumpetera i njegove postavke o politički utemeljenim socijetalnim ciklusima. Ne manje važna su i njegova upozorenja na važnost doprinosa američkog institucionalnog ekonomista Johna Commonsa i njegova isticanja važnosti države u reguliranju gospodarstva u razdobljima ekonomskih kriza. ${ }^{5}$ Ključna je zadaća političke ekonomije, prema Strpićevu mišljenju, da analizira takve cikluse, $s$ time da operativna rješenja za njih spadaju u oblikovanje javnih politika. Time on povezuje svoja analitička razmatranja utemeljena u političkoj ekonomiji s disciplinom javnih politika, čime je dao trajan doprinos domaćoj političkoj znanosti.

\section{Marxova kritika političke ekonomije između klasične škole i moderne ekonomske znanosti}

Marxova kritika političke ekonomije, čija je evolucija pomno prikazana u Strpićevoj knjizi (Strpić, 2017), pokazuje se kao koherentan sustav koji prikazuje funkcioniranje i razvitak kapitalističkog načina proizvodnje. Strpić uvjerljivo pokazuje kako je nastao takav sustav i koji su temeljni zakoni njegova daljnjeg razvitka. No to je sustav mišljenja koji ostaje unutar klasične tradicije i političke ekonomije nastale prvenstveno u radovima Smitha i Ricarda, u kojem nema mjesta za radove i autore

5 Sustavan pregled Commonsovih doprinosa institucionalnoj ekonomiji može se pronaći u radu Malcolma Rutherforda (1983). 
izvan te tradicije. Stoga, kao što je svojevremeno upozorio Zvonimir Baletić, Marx nije ni uključio mnoga važna pitanja u svoj plan rada. "Marxovo djelo ostaje bitno u okviru klasičnog načina ekonomskog rezoniranja” (Baletić, 1968: 594). Njega stoga ne zanimaju brojni teorijski pokušaji i inovacije koji izlaze izvan okvira klasične škole. Riječ je o nizu autora koji svoje radove objavljuju još za Marxova života, a koje on nije praktički ni spomenuo u svojim radovima. Baletić navodi primjere Juglara, Cournota, Jevonsa, Mengera, a podrobnija analiza povijesti ekonomske misli i metode, poput one koju je priredio Blaug (1985), mogla bi ukazati na još niz autora.

To nas dovodi do problema na koji je još sredinom 1930-ih ukazao poznati poljski ekonomist Oskar Lange. Raspravljajući o odnosu Marxove političke ekonomije i moderne ekonomske teorije, Lange $(1935)^{6}$ je naglasio da distinktivnu crtu marksističkog pristupa i pristupa građanskih ekonomista predstavlja sposobnost objašnjenja temeljnih tendencija u razvoju kapitalističkog sistema. Marksistička ekonomija razvila je teorijske koncepcije temeljem kojih je, prema njegovu sudu, moguće objasniti logiku evolucije kapitalističkog sistema. Moderna građanska ekonomska znanost, smatra Lange, takvu teoriju nije nastojala uključiti u svoj teorijski okvir, već je te procese prepuštala ekonomskoj povijesti, ostavljajući ih izvan korpusa ekonomske teorije. Posljedica toga jest činjenica da građanska ekonomska znanost nema što reći o logici razvoja kapitalističkog sustava, primjerice o transformaciji kapitalističkog sustava slobodne konkurencije 19. stoljeća u monopolistički kapitalizam 20. stoljeća, o nadomještanju laisser-fairea državnom intervencijom i planiranjem, a slobodne trgovine ekonomskim protekcionizmom i nacionalizmom te svim ostalim bitnim tendencijama u razvoju kapitalizma. No istodobno, navodi Lange, postoje i silni problemi marksističke političke ekonomije u objašnjenju ključnih procesa tekuće dinamike kapitalističkih društva. "Što Marxova ekonomija može reći o monopolističkim cijenama? Što ima reći o fundamentalnim problemima kreditne i monetarne teorije? Kakvu aparaturu može ponuditi za analiziranje porezne incidence ili učinka određenih tehničkih inovacija na nadnice? I (ironija sudbine) na koji način Marxova ekonomija može doprinijeti problemu optimalne raspodjele proizvodnih resursa u socijalističkoj privredi?” (Lange, 1935: 191). Temeljem toga Lange zaključuje da "Marxova ekonomija i moderna 'buržoaska' ekonomska teorija pripadaju različitim 'rangovima"' (ibid.). Isticanjem činjenice o različitim razinama objašnjenja tih dviju orijentacija ekonomske znanosti on želi istaći da za razliku od Marxove političke ekonomije, koja može puno toga reći o zakonima evolucije kapitalističkog društva,

${ }^{6}$ Langeov je članak kasnije uvršten u zbornik pod naslovom Marx and Modern Economics koji je uredio David Horowitz (1968). Zbornik predstavlja jedan od najboljih prikaza odnosa Marxove ekonomske teorije i dominantnih tokova ekonomske znanosti. Osim spomenutog Langeovog priloga u zbornik su uvršteni radovi velikih imena ekonomske misli 20. stoljeća kao što su Mark Blaug, Maurice Dobb, Lawrence R. Klein, Wassily Leontief, Joan Robinson i drugi. 
građanska ekonomija o tome može dati tek površne opise. No, s druge strane, građanska ekonomija daje superiorne ekonomske analize ključnih tema svakodnevnih ekonomskih procesa u odnosu na marksističke interpretacije.

Građanska ekonomija se nakon velike ekonomske krize krajem 1920-ih i početkom 1930-ih, dakako, postupno vratila temama koje je napustila nakon Marxa. To se poglavito odnosi na pitanja akumulacije kapitala i razvoja, kao što upozorava Baletić (1968), tako da strogu Langeovu ocjenu valja razumjeti isključivo u kontekstu sredine 1930-ih u kojem on piše svoj pregledni rad. Naime, u tom trenutku Keynesova Opća teorija zaposlenosti, kamate i novca još nije objavljena; u javnosti se pojavila tek 1936, godinu dana nakon Langeova članka. No godinu dana prije njegova članka, 1934, objavljena je ključna Commonsova studija o institucionalnoj ekonomiji, u kojoj on podastire neortodoksnu analizu o potrebi intervencije države u ekonomiju u razdoblju krize (Commons, 1934).

U desetljećima koja su slijedila niz je poznatih ekonomista pokušao unaprijediti Marxovu teoriju korištenjem funkcija i matematičkih modela, nastojeći je podvesti pod različite vrste modela koji bi bili usporedivi s drugim radovima suvremene ekonomske znanosti. U već spomenutom zborniku koji je uredio Horowitz, japanski politekonomist Shigeto Tsuru pokušao je povezati Marxove nalaze s nalazima Johna M. Keynesa (Tsuru, 1968). Jedan drugi japanski ekonomist, Michio Morishima, pokušao je Marxovu teoriju uklopiti u matematičke modele navodeći da postoje dva pravca u upotrebi takvih modela - prvi, u kojem se postojeći matematički modeli primjenjuju na ekonomska pitanja, za što je kao paradigmatski primjer naveo Cournota, te drugi, kojim se predviđaju matematički problemi unutar ekonomije. Pritom je Marxa svrstao u drugu kategoriju te je pokušao razmotriti njegove fundamentalne teoreme i poznati transformacijski problem (Morishima, 1974: 611). Najdalje u primjeni matematičkih pristupa na Marxove teorijske postavke u posljednje vrijeme otišla je skupina ekonomskih istraživača s američkih i europskih sveučilišta koja je, razmotrivši jezikom formalne analize Marxovu radnu teoriju vrijednosti, došla do radikalno negativnih nalaza o njezinoj znanstvenoj vrijednosti. Ustvrdili su da je "ključna, distinktivna zasada Marxove ekonomije, radna teorija vrijednosti, u najboljem slučaju irelevantna i vjerojatno nedosljedna u logičkom pogledu" (Cogliano, Flaschel, Franke, Fröhlich i Veneziani, 2018: 377).

Na ovome mjestu nije moguće ulaziti u brojne druge radove u kojima se Marxova ekonomska teorija povezuje sa suvremenom ekonomskom teorijom, a još manje u tumačenje opravdanosti svih kritika koje su iznesene u tim analizama. Umjesto toga htjeli smo s tek nekoliko primjera ilustrirati tvrdnju da je rasprava o Marxovoj kritici političke ekonomije ne samo u smislu vjerodostojnosti njezine kritike klasične škole nego i u smislu relevantnosti za suvremenu ekonomsku znanost još uvijek vrlo živa i izrazito plodonosna. 


\section{Zaključak}

Čitanje Strpićeve knjige Robna proizvodnja i udruženi rad u Marxovoj kritici političke ekonomije otkriva nam jasan okvir unutar kojeg je Marx izveo svoju teoriju kapitalističkog načina proizvodnje. Minuciozna analiza Marxova teorijsko-metodološkog pristupa u Kapitalu i drugim radovima omogućila mu je da do kraja shvati važnost robne proizvodnje za razumijevanje kapitalističkog načina proizvodnje. Zbog toga je i mogao, kako i sam ističe, još od sredine 1970-ih u nizu svojih radova isticati "ne samo postojanje kapitala u socijalističkim sustavima (pa i jugoslavenskom samoupravnom), nego i to da kapital u njima ostaje temeljni odnos društvene proizvodnje i reprodukcije" (Strpić, 2010: 83). Strpić je tih godina bio jedan od rijetkih politekonomista koji se u tadašnjoj Jugoslaviji usudio izlaziti s takvim stavovima, tvrdeći da je u nas i dalje na djelu kapital-odnos. Kasnije mu se u zastupanju takvih stavova priključio i njegov dugogodišnji suradnik, istaknuti slovenski politekonomist Bogomir Kovač, koji je u to doba objavio jedan od najsustavnijih prikaza Marxove kritike političke ekonomije (Kovač, 1988).

Marxova politička ekonomija, kao što Strpić pokazuje u nizu svojih radova, a ne samo u knjizi koja je predmet razmatranja u ovome tekstu, predstavlja neku vrstu integrativne analize ekonomije, društva i politike. Ili, da se poslužimo njegovim riječima, ona nastaje na "mjestima preklapanja i sučeljavanja političke i ekonomske znanosti, odnosno, politike i privrede" (Strpić, 2015: 37). Politička ekonomija stoga spomenuta područja ne razmatra kao izdvojene elemente, već kao međusobno ovisne strukture koje se povijesno razvijaju. A upravo su strukture i njihova dinamika razvoja temeljno polazište institucionalizma u ekonomskoj teoriji, koje ga razlikuje od pristupa koji ishodište vide u pojedincu ili različitim vrstama kolektiviteta.

Nakon završetka doktorske disertacije (1991) Strpić se stoga vrlo snažno okrenuo proučavanju institucionalne ekonomije. Od autora koji pripadaju tom pravcu ekonomske misli posebno je isticao važnost Johna Commonsa i njegovih radova inicijalno objavljenih 1920-ih i 1930-ih. Pozivajući se na njega, Strpić njegove doprinose naziva "Commonsovim pravilom", ističući "da su teška vremena kriza obično razdoblja intervencionističkih, na državu orijentiranih ideja i politika. A dobra vremena konjunktura razdoblja su tržišno orijentiranih koncepata i u teorijama i u praktičnom djelovanju" (Strpić, 2010: 190). ${ }^{7}$ Strpić je na taj način pokazao da je na tragu onog što je u jednom svom radu pokazao talijanski politekonomist Ugo Pagano, ističući da se neki dijelovi Marxove kritike političke ekonomije, kombinirani sa starim institucionalizmom (u koji, bez daljnjeg, spada i Commons), mogu

7 Johna Commonsa se pritom, u preglednoj literaturi o institucionalnoj ekonomiji, ocjenjuje kao autora koji je među predstavnicima starog institucionalizma možda i najbliže autorima koje označavamo novim institucionalistima (Hodgson, 2003). 
upotrijebiti kao ozbiljan doprinos daljnjem razvoju novog institucionalizma u ekonomiji (Pagano, 2007).

Zbog toga nam se čini da bi u daljnjim istraživanjima Strpićeve ostavštine moglo biti posebno zanimljivo povezivanje njegovih istraživanja podastrtih u knjizi Robna proizvodnja i udruženi rad u Marxovoj kritici političke ekonomije (Strpić, 2017) s istraživanjima političko-ekonomskog razvoja koji elaborira u knjizi Promjena: političko-ekonomska promjena od Hobbesa do Hayeka (Strpić, 1998) i u trećem dijelu knjige Karl Marx i politička ekonomija Moderne (Strpić, 2010). Kombinirano čitanje tih radova usporedo s bogatom literaturom koju je ostavio u silabusima svojih predavanja o političkoj ekonomiji i ekonomskoj povijesti, s brojnim i vrijednim opaskama o ključnih autorima klasične i nove političke ekonomije te političkog razvoja, jamčit će nastavak razvoja političke ekonomije kao discipline koju je utemeljio kao dugogodišnji profesor na Fakultetu političkih znanosti u Zagrebu.

\section{LITERATURA}

Ankarloo, Daniel/Palermo, Giulio, 2004: Anti-Williamson: A Marxian Critique of New Institutional Economics, Cambridge Journal of Economics (28) 3: 413-429.

Baletić, Zvonimir, 1968: Marxova politička ekonomija i suvremena ekonomska znanost, Politička misao (5) 4: 590-598.

Becker, James F., 1977: Marxian Political Economy: An Outline, Cambridge University Press, Cambridge.

Bidet, Jacques, 2008: A Key to the Critical Companion to Contemporary Marxism, u: Bidet, J. i Kouvelakis, S. (ur.): Critical Companion to Contemporary Marxism, Brill, Leiden i Boston: 3-22.

Blaug, Mark, 1985: Economic Theory in Retrospect, Cambridge University Press, Cambridge.

Cogliano, Jonathan F./Flaschel, Peter/Franke, Reiner/Fröhlich, Nils/Veneziani, Roberto, 2018: Value, Competition and Exploatation: Marx's Legacy Revisited, Edward Elgar, Cheltenham.

Commons, John R., 1934: Institutional Economics: Its Place in Political Economy, Transaction Books, New Brunswick.

Dorman, Peter, 1991: Marxism, Methodological Individualism and the New Institutional Economics: Further Considerations, Journal of Institutional and Theoretical Economics (147) 3: 364-374.

Dugger, William M./Sherman, Howard J., 1994: Comparison of Marxism and Institutionalism, Journal of Economic Issues (28) 1: 101-127. 
Ehrbar, Hans G., 2000: Critical Realist Arguments in Marx's Capital, u: Brown, A., Fleetwood, S. i Roberts, J. M. (ur.): Critical Realism and Marxism, Routledge, London i New York: 43-56.

Ehrbar, Hans G., 2010: Annotations to Karl Marx’s 'Capital'. https://content.csbs.utah. edu/ ehrbar/akmc.htm, posljednji put pristupljeno 2. 6. 2020.

Foley, Duncan F., 1986: Understanding Capital: Marx's Economic Theory, Harvard University Press, Cambridge, MA.

Franičević, Vojmir, 2003: Pogovor: Douglass C. North: Od nove ekonomske povijesti do novog institucionalizma, u: North, Douglass C., Institucije, institucionalna promjena i ekonomska uspješnost, Masmedia, Zagreb: 205-246.

Heijdra, Ben J./Lowenberg, Anton D./Mallick, Robert J., 1988: Marxism, Methodological Individualism, and the New Institutional Economics, Journal of Institutional and Theoretical Economics (144) 2: 296-317.

Hodgson, Geoffrey M., 2003: John R. Commons and the Foundations of Institutional Economics, Journal of Economic Issues (37) 3: 547-576.

Hollander, Samuel, 2008: The Economics of Karl Marx: Analysis and Application, Cambridge University Press, Cambridge.

Horowitz, David (ur.), 1968: Marx and Modern Economics, Monthly Review Press, New York.

Howard, Michael C./King, John E., 1985: The Political Economy of Marx, New York University Press, New York.

Immergut, Ellen, 1998: The Theoretical Core of the New Institutionalism, Politics and Society (26) 1: 5-34.

Itoh, Makoto, 1978: The Formation of Marx's Theory of Crisis, Science \& Society (42) 2: $129-145$.

Kovač, Bogomir, 1988: Način proizvodnje i kritika političke ekonomije, Naše teme, Zagreb.

Kursar, Tonči, 1997: Mancur Olson: Politička ekonomija interesnih grupa, Politička misao (34) 2: 192-202.

Lalović, Dragutin, 2017: Marxovo nasljeđe kao zadaća mišljenja (pogovor), u: Strpić, D., Robna proizvodnja i udruženi rad u Marxovoj kritici političke ekonomije, Disput, Zagreb: 439-484.

Lange, Oskar, 1935: Marxian Economics and Modern Economic Theory, Review of Economic Studies (2) 3: 189-201.

Marx, Karl, 1977a: Kapital II, u: Marx, K. i Engels, F., Dela, sv. 22, Institut za izučavanje radničkog pokreta i Prosveta, Beograd.

Marx, Karl, 1977b: Kapital III, u: Marx, K. i Engels, F., Dela, sv. 23, Institut za izučavanje radničkog pokreta i Prosveta, Beograd. 
Marx, Karl, 1979: Osnovi kritike političke ekonomije, u: Marx, K. i Engels, F., Dela, sv. 19, Institut za izučavanje radničkog pokreta i Prosveta, Beograd.

Meek, Ronald L., 1977: Smith, Marx, and After, John Wiley \& Sons, New York.

Morishima, Michio, 1974: Marx in the Light of Modern Economic Theory, Econometrica (42) 4: 611-632.

Nee, Victor, 1998: Sources of the New Institutionalism, u: Brinton, M. C. i Nee, V. (ur.): The New Institutionalism in Sociology, Stanford University Press, Stanford: 1-16.

North, Douglass C., 1986: Is it Worth Making Sense of Marx?, Inquiry: An Interdisciplinary Journal of Philosophy (29) 1-4: 57-63.

North, Douglass C., 2003: Institucije, institucionalna promjena i ekonomska uspješnost, Masmedia, Zagreb.

O'Connor, James, 1981: The Meaning of Crisis, International Journal of Urban and Regional Research (5) 3: 301-329.

O'Hara, Phillip Anthony, 2000: Marx, Veblen, and Contemporary Institutional Political Economy: Principles and Unstable Dynamics of Capitalism, Edward Elgar, Aldershot.

Olson, Mancur, 2009: Logika kolektivnog djelovanja: javna dobra i teorija skupina, Fakultet političkih znanosti, Zagreb.

Pagano, Ugo, 2007: Karl Marx after New Institutional Economics, Evolutionary and Institutional Economics Review (4) 1: 27-53.

Rutherford, Malcolm, 1983: J. R. Commons's Institutional Economics, Journal of Economic Issues (17) 3: 721-744.

Strpić, Dag, 1998: Promjena: Politička i političko-ekonomska promjena od Hobbesa do Hayeka, Fakultet političkih znanosti, Zagreb.

Strpić, Dag, 2010: Karl Marx i politička ekonomija Moderne, Nacionalna zajednica Crnogoraca Hrvatske i Disput, Zagreb.

Strpić, Dag, 2015: Prema Novoj političkoj ekonomiji, Disput, Zagreb.

Strpić, Dag, 2017: Robna proizvodnja i udruženi rad u Marxovoj kritici političke ekonomije, Disput, Zagreb.

Tsuru, Shigeto, 1968: Keynes vs. Marx: The Methodology of Aggregates, u: Horowitz, D. (ur.): Marx and Modern Economics, Monthly Review Press, New York: 176-202. 


\title{
Zdravko Petak \\ CONTEMPORARY SCIENTIFIC RELEVANCE OF MARX'S ANALYSIS OF CAPITAL
}

\begin{abstract}
Summary
The paper discusses the relevance of Marx's analysis of capital and the manner in which that contribution is presented in the book on Marx's critique of political economy written by Dag Strpić. At the beginning of the paper, the author indicates some elements of the general theoretical framework within which Strpić formulated his research on Marx's critique of political economy. The paper raises two fundamental questions concerning Marx's critique of political economy: 1. Can a fundamental starting point be drawn from Marx's theoretical framework for understanding the importance of institutions in the economic process, as seen by the representatives of old and new institutionalism in political economy? 2. Can a unique explanation of economic crises be derived from reading Marx's categorical apparatus? The answer to the first question shows that there are certain similarities between Marx's approach and the approach advocated by economic institutionalists, but also there exist significant differences between the two approaches. The answer to the second question shows that Marx did not develop a unique theory of crises, since there are arguments indicating the existence of two or three different crisis theories which can be found in his work.

After that, the author shows, using most general terms, that Marx's critique of political economy is primarily situated by his attitude towards the classical school, but that it also has some potential to correspond with modern economics. The author shows that the direction of correspondence refers primarily to the explanation of fundamental tendencies in the development of the capitalist system. The conclusion of the paper reviews some of Strpić's fundamental contributions to political economy.
\end{abstract}

Keywords: Marx's Critique of Political Economy, Institutionalism in Political Economy, Marx's Theory of Crisis, Marx and Modern Economics, Strpić

Zdravko Petak je profesor javnih politika na Fakultetu političkih znanosti Sveučilišta u Zagrebu.

Kontakt: Zdravko Petak, Fakultet političkih znanosti, Ivana Lepušića 6, 10000 Zagreb, Hrvatska. E-mail: zdravko.petak@fpzg.hr 